\title{
En demanda de lo justo: conflictos por derechos en la Patagonia petrolera. Comodoro Rivadavia, 1932
}

\author{
Andrea Andújar \\ CONICET/IIEGE-UBA/UNP
}

\section{Resumen}

Este trabajo explora de qué manera ciertos trabajadores y trabajadoras vinculadas a la actividad petrolera en Comodoro Rivadavia edificaron nociones sobre lo justo. Para ello, examina las demandas por derechos expresadas en las huelgas que tuvieron lugar durante la primera mitad del año 1932, situando tales nociones, reivindicaciones y protestas en un entramado de relaciones que involucró tanto el ámbito productivo como el de la vida comunitaria y el hogar.

\section{Palabras claves}

Clase obrera, género, nociones de lo justo, huelgas petroleras, Comodoro Rivadavia

\begin{abstract}
This paper explores the ways in which certain male and female workers related to the petroleum activity at Comodoro Rivadavia constructed notions about justice. Therefore, it examines the demands for rights expressed at the strikes that took place during the first half of 1932, placing such notions, claims and protests in a network of relations that involved the productive environment such as the community and household life.
\end{abstract}

\section{Keywords}

Working class, gender, rights, notions of justice, petroleum strikes, Comodoro Rivadavia 


\section{En demanda de lo justo: conflictos por lo justo en la Patagonia petrolera}

La experiencia surge espontáneamente en el interior del ser social, pero no surge sin pensamiento; surge porque los hombres y las mujeres (y no sólo los filósofos) son racionales y piensan acerca de lo que les ocurre a ellos y a su mundo". ${ }^{1}$

\section{Introducción}

El 5 de agosto de 1932 El Obrero Petrolero, un periódico confeccionado y distribuido clandestinamente en Comodoro Rivadavia por trabajadores militantes del Partido Comunista, publicaba algunos fragmentos de una carta firmada por un obrero, un tal B. Rey. El objetivo inicial de la misiva era dar a conocer el arresto y posterior encarcelamiento del que había sido víctima el 19 de abril de ese año. Rey contaba que ese día, mientras esperaba su turno para ser atendido en la peluquería "Nueva York", situada en una de las calles del pueblo -como se denominaba popularmente en ese entonces a la pequeña ciudad de Comodoro Rivadavia-, un policía entró al local y lo obligó a acompañarlo a la comisaría. Una vez allí, el comisario de apellido González comenzó a interrogarlo a propósito de un "manifiesto" hallado en su poder que hablaba en contra de "Justo 4144 y su perro faldero De Tomaso y sus bandas fascistas". ${ }^{2}$ A pesar del enojo cada vez más visible del funcionario por el contenido del texto, B. Rey no estaba dispuesto a revelarle de dónde lo había sacado, dando por toda respuesta que tan sólo lo había encontrado.

Seguramente, González no tardó demasiado tiempo en deducir la autoría del escrito. Las referencias al gobierno de Agustín P. Justo anexando a su apellido el número de la Ley de Residencia eran habituales en los panfletos y periódicos de los comunistas. También era frecuente la mención a las "bandas fascistas" para aludir a aquellas organizaciones de ultraderecha que, como la Liga Patriótica o las recientemente creadas Legión Cívica Argentina y la Sección Especial de la Policía, contaban con el beneplácito gubernamental para perseguir a los opositores políticos y en particular, a los de esa organización de izquierda. Tampoco era inusual en ellos calificar a los ministros del Poder Ejecutivo nacional como "perros falderos", tal como se hacía en este caso con el de la cartera de Agricultura, Antonio De Tomaso.

Para el comisario, al igual que para las autoridades del municipio de Comodoro Rivadavia y las dirigencias de las empresas petroleras radicadas al norte de la localidad, la presencia de los comunistas se había vuelto una amenaza seria. Desde inicios de la década de 1930, cuando algunos activistas habían arribado a la zona, el Partido Comunista no sólo había conseguido articularse localmente creando a su vez filiales de la Federación Juvenil Comunista (FJC) y del Socorro Rojo Internacional (SRI). También había impulsado la fundación de la Unión General de Obreros Petroleros (UGOP), un sindicato que desde su aparición

\footnotetext{
${ }^{1}$ Edward P. Thompson. E. P. Miseria de la Teoría. Barcelona, Crítica, 1981; [pág. 19].

2 El Obrero Petrolero, 3 de agosto de 1932, "Carta de los obreros"; [pág. 4]. Fondo Documental "Enrique Mosconi. Asuntos de YPF; Personal obrero de Yacimientos Comodoro Rivadavia. Expedientes de la Dirección General". Caja N 8, Museo del Petróleo, Comodoro Rivadavia.
} 


\section{Andrea Andújar}

a mediados de 1931 había afiliado alrededor de 3.600 obreros. ${ }^{3}$ Más aún: en lo que iba de 1932, cuando la desocupación y el costo de vida continuaban incrementándose como resultado de la recesión provocada por la crisis de 1929, la UGOP había lanzado desde la clandestinidad dos huelgas, una en febrero y otra en abril, que comprometieron a la mayoría de las compañías petroleras. Fue justamente durante la segunda de estas protestas cuando se produjo el arresto de B. Rey.

Posiblemente, el tenso clima social imperante y la sospecha de que entre otras estratagemas para evitar ser detectados, los trabajadores comunistas se reunían en el pueblo a fin de sortear la estrecha vigilancia en los campamentos petroleros, que a veces intentaban disimular estos encuentros usando locales comerciales y que en alguno de ellos debían tener escondida su imprenta, condujeron al comisario González a considerar el hallazgo del "manifiesto" como prueba suficiente de las simpatías políticas de su portador. Decidió entonces encerrarlo en el calabozo, donde las cosas se pondrían más difíciles ya que Rey quedaba incomunicado y a merced del rigor del frío pues el oficial no le permitió "entrar ninguna pilcha" a pesar de conocer su "delicado estado de salud". ${ }^{4}$ Llevaba 22 horas en la celda, soportando la situación como podía, cuando la intervención de su esposa torció su destino. Enterada de su detención y aún cuando también estaba enferma, la mujer se presentó en la comisaría con sus pequeños hijos y armó un escándalo de tal magnitud que el comisario resolvió aceptar lo que ella le exigía: liberar a su marido. Luego de precisar la manera en que su cautiverio finalizó, Rey concluía la carta interpelando a los y las lectoras del periódico con una pregunta: ¿¿Donde estará el derecho de pensar, de leer y de hablar que todavía desconoce el comisario Gonzalez?". 5

El relato de este episodio brinda un conjunto de indicios sobre las concepciones y valores que hacían a la cultura política de ciertos trabajadores y trabajadoras vinculadas a la actividad petrolera en Comodoro Rivadavia, y que fueron esgrimidos en términos de derechos. En principio, permite apreciar la importancia atribuida al derecho de profesar determinadas ideas y expresarlas -y por tanto, difundirlas- en voz alta y abiertamente. También revela los riesgos que su ejercicio podía entrañar así como las iniciativas puestas en práctica para su

\footnotetext{
${ }^{3}$ Rufino Gómez. La gran huelga petrolera de Comodoro Rivadavia (1931-1932) en el recuerdo de un militante obrero y comunista. Buenos Aires, Centro de Estudios, 1973. No se dispone de censos poblacionales de los campamentos petroleros existentes en la región. De todos modos, se calcula que para ese momento en el campamento de Yacimientos Petrolíferos Fiscales (YPF), la compañía más importante, la población rondaba en 7000 personas, comprendiendo tal cifra una fuerza laboral compuesta de 3.000 obreros y 500 empleados. Esto permite vislumbrar el alcance del predicamento de la UGOP. Véase Daniel Cabral Marques. "La expansión de los yacimientos estatales en la Patagonia austral y la consolidación de un modelo de regulación sociolaboral bajo la égida de YPF: 1930-1946"; en Enrique Mases (comp.). Trabajadores y Trabajadoras en la Argentina. Aportes para una Historia social. Neuquén, Editorial de la Universidad Nacional del Comahue, 2011.

${ }^{4}$ El Obrero Petrolero, 3 de agosto de 1932, "Carta de los obreros"; [pág. 4]. Fondo Documental "Enrique Mosconi. Asuntos de YPF; Personal obrero de Yacimientos Comodoro Rivadavia. Expedientes de la Dirección General". Caja № 8, Museo del Petróleo, Comodoro Rivadavia.

${ }^{5}$ Ibídem.
} 


\section{En demanda de lo justo: conflictos por lo justo en la Patagonia petrolera}

defensa, algunas de las cuales llegaban a ser incluso inesperadas. De tal modo, si ser encontrado leyendo un "manifiesto" del Partido Comunista era motivo suficiente para perder la libertad, presentarse en la comisaría con niños pequeños y dispuesta a hacer un gran alboroto podía constituir un acto lo suficientemente imprevisto como para doblegar la voluntad de un oficial de la policía.

Esas acciones sugieren, a su vez, cómo ciertos constructos de género incidieron en la experiencia de esas mujeres y varones trabajadores, delineando en este caso solidaridades y reacciones ante situaciones adversas en el marco del conflicto de clases. En ese sentido, si el apresamiento de B. Rey involucró inicialmente escenarios públicos/políticos poblados por varones (la peluquería, la comisaría) y si las circunstancias causantes del mismo radicaban en las sospechas sobre su adscripción política en tanto trabajador y en un contexto específico, el de una huelga, su suerte se dirimió con la intervención de su mujer quien movilizando sentidos relativos a su rol de esposa y madre, se enfrentó al policía en resguardo en definitiva, de la integridad de su hogar proletario.

Finalmente, los valores, ideas y prácticas retratadas en la carta de B. Rey posibilitan inquirir sobre las nociones de lo justo que sustentaron los derechos enunciados y defendidos por esos varones y mujeres trabajadoras. Es hacia allí donde este artículo orienta su interés, proponiéndose realizar una primera aproximación a la reconstrucción de tales nociones y de los significados de los términos en las que fueron expresadas. Para ello, examina las reivindicaciones planteadas en las huelgas desatadas en esas comunidades obreras durante la primera mitad del año 1932, entendiendo que esas exigencias no fueron mecánico reflejo de las condiciones estructurales sino más bien, fruto de la manera en que los y las trabajadores experimentaron sus condiciones de explotación en un particular entramado histórico, pensaron el mundo en que vivían y en el que querían vivir, e identificaron sus intereses a través de conflictos y negociaciones no sólo con sus contrincantes de clase sino también entre sí.

Por otro lado, situar esas concepciones sobre lo justo y las exigencias a que dieron lugar en la experiencia de los y las trabajadoras implica aquí tomar en cuenta aspectos de su vida tanto en el ámbito de trabajo como en el de la comunidad y el hogar. Estos espacios externos al lugar de labor revisten interés pues los lazos de sociabilidad que se tejieron en ellos contribuyeron a entablar relaciones de confianza, intercambiar información y percepciones sobre la realidad circundante y también, discutir y decidir qué hacer frente al cotidiano laboral y social. Dicho de otro modo, lo que se sostiene en este artículo es que examinar cómo las y los trabajadores experimentaron su condición de clase tanto en el pozo como en la comunidad, en el taller como en el hogar, en la escuela como en el club deportivo y social, posibilita reconstruir más densamente la forma en que edificaron sus nociones de lo justo y sus demandas por derechos.

A fin de develar unas y otras así como las acciones colectivas de protesta en las que se pusieron en escena, se ha recurrido a la revisión de un acervo documental compuesto por la prensa local (fundamentalmente, el diario El 


\section{Andrea Andújar}

Chubut), la prensa política y sindical (básicamente, la orientada por anarquistas, socialistas y comunistas), memorias, circulares internas y fichas del personal de la empresa Yacimientos Petrolíferos Fiscales (YPF) en Comodoro Rivadavia, notas elevadas por las autoridades municipales al gobierno del Territorio Nacional del Chubut -del cual formaba parte Comodoro Rivadavia-, los recuerdos de un militante comunista, diversos expedientes judiciales y policiales de la región, y los libros de partes diarios de la guardia policial pertenecientes a la comisaría situada dentro del campamento central de YPF. Interrogados en una clave analítica que combina la perspectiva de la historia social y los estudios de género, este trabajo procura en suma, comprender las acciones políticas, tradiciones y valores en base a los cuales la clase obrera petrolera de Comodoro Rivadavia articuló sus nociones de lo justo y sus demandas por derechos, confrontando con sus patrones de manera abierta en algunas ocasiones y solapadamente en otras, para hacerlos valer.

Para cumplir tal cometido, las páginas que siguen comienzan por esbozar algunas aristas de la vida en los campamentos petroleros de Comodoro Rivadavia y reseñar las huelgas de 1932, destacando las reivindicaciones de los y las trabajadores. Los sentidos de justicia que las atravesaron, los espacios en los que se edificaron y algunas de las diversas expresiones colectivas e individuales que en torno a exigencias por derechos pueden advertirse en ambos conflictos, constituyen la materia de análisis de la segunda parte de este artículo.

\section{Aspectos de la vida y las protestas en los campamentos petroleros}

Para inicios de la década de 1930, Comodoro Rivadavia era una región central de la actividad petrolera de la Argentina. En su territorio, se diseminaban los campamentos de la empresa estatal YPF -fundada en 1922 a partir de la reorganización de la Dirección General de Explotación del Petróleo de Comodoro Rivadavia creada en 1910 y cuya presencia era dominante- y de las compañías de capitales privados Diadema Argentina, ASTRA de Petróleo Argentina, Manantial Rosales y la Compañía Ferrocarrilera de Petróleo (COMFERPET). ${ }^{6}$

Sintéticamente, puede decirse que estos asentamientos surgidos en las décadas de 1910 y 1920 en una geografía marcada por severas condiciones climáticas, conformaban una comunidad ocupacional gestada en torno a una actividad específica (la extracción hidrocarburífera), dispuesta dentro de unos límites físicos acotados (los predios aledaños a las ubicaciones de los pozos) que comprendían en su interior el lugar del trabajo y el lugar donde se habitaba y se satisfacían un conjunto de necesidades ligadas a la educación, la salud, el consumo y el uso del tiempo libre. A ello pueden sumarse otras tres características, al menos. La primera era el relativo aislamiento de los campamentos respecto del centro urbano de Comodoro Rivadavia pues todos estaban situados algunos

${ }^{6}$ Carl Solberg. Petróleo y nacionalismo en la Argentina. Buenos Aires, Hyspamérica, 1986. 
kilómetros al norte del pueblo. Así, por ejemplo, el campamento central de YPF distaba tres kilómetros en esa dirección mientras que el de la compañía Diadema Argentina, creada en 1922, se localizaba a 27 kilómetros. La segunda remite a la relativa autonomía política de la cual gozaban las compañías petroleras respecto del poder municipal local, que se tradujo en cuestiones tales como el establecimiento de prohibiciones que regían dentro de los campamentos y que no se homologaban fuera de sus fronteras o la abierta exclusión de la participación política de los trabajadores petroleros en el destino municipal. ${ }^{7}$ Una última distinción radica en quienes formaban parte de la fuerza de trabajo. Dominantemente masculina, la mano de obra abocada a las tareas de esta industria reconocía múltiples orígenes nacionales. Así, entre esos varones que trabajan en la perforación y extracción de los pozos petroleros, en la construcción o en los talleres y almacenes de los campamentos, se contaban españoles, portugueses, italianos, búlgaros, alemanes, polacos, rusos, griegos, ingleses, yugoslavos, rumanos, chilenos y en menor medida, argentinos. Por su parte, las mujeres, también de distintas procedencias nacionales y con una presencia numérica menor que la de los varones, además de las tareas relativas al cuidado de la familia, llegaban a emplearse como costureras, lavanderas y planchadoras por cuenta propia para los trabajadores petroleros, como asalariadas de las empresas para la atención de los baños públicos instalados en los campamentos, en el ejercicio de la docencia dentro de las escuelas que funcionan allí, como cocineras y mucamas en las casas del personal jerárquico y paulatinamente, como trabajadoras administrativas de las empresas. ${ }^{8}$ Un ejemplo sobre la disposición y ocupación de los espacios en los campamentos lo ofrece COMFERPET, la compañía en la que se inició la primera de las huelgas de 1932.

Como ocurría en YPF o ASTRA, esta empresa, originada hacia fines del año 1920 a partir de la asociación de tres firmas ferroviarias inglesas y ubicada a 8 kilómetros al norte del pueblo, favorecía la localización de la población trabajadora en las inmediaciones de su yacimiento y sede administrativa, proveyendo un conjunto de servicios tendientes a resolver algunas de las necesidades de los obreros y sus familias. Así, en torno a las instalaciones correspondientes a los talleres, la refinería y las oficinas administrativas, se erigieron pabellones para trabajadores solteros, barracas con pieza y cocina para los casados y sus familias, baños de uso colectivo, gamelas, un almacén y un negocio de ramos generales. La atención de la salud, la educación y el uso del tiempo libre también estuvieron

\footnotetext{
7 Entre tales prohibiciones, estaba la del establecimiento de casas de tolerancia dentro de los campamentos. Por otro lado, a partir de 1917, quienes residían en ellos quedaron excluidos de la participación en las elecciones municipales al determinase que los asentamientos petroleros no integraban el ejido municipal.

${ }^{8}$ Para un estudio sobre las tareas asalariadas desempeñadas por las mujeres en los campamentos petroleros, particularmente en ASTRA e YPF, véase Graciela Ciselli. "Trabajo femenino en la industria petrolera de Chubut (1910-1962)" en Revista Andes, N 13, 2002, y "El trabajo femenino en una empresa petrolera privada patagónica. Cambios y continuidades durante el siglo XX" en Revista Avá, № 7, junio de 2003.
} 


\section{Andrea Andújar}

presentes en las preocupaciones de la dirigencia de la compañía, quien destinó predios dentro del campamento para la construcción de una enfermería, un hospital -inaugurado en 1931-, una escuela para los hijos e hijas de los trabajadores, un club recreativo y deportivo -fundado en 1924 y donde se realizaban competencias de atletismo y encuentros futbolísticos-, y un gimnasio en el que a comienzos de la década de 1930 comenzaron a proyectarse películas sonoras en blanco y negro. ${ }^{9}$

Puede suponerse, como lo proponen algunos estudios, que estas políticas empresariales afines a la modalidad de explotación capitalista intensiva y prohijadas además por la distancia geográfica entre los campamentos y el pueblo, buscaron atraer, afincar y obtener una mano de obra estable y disciplinada. Bajo esa perspectiva, la provisión de viviendas, la facilitación del abastecimiento de bienes de primera necesidad, la atención de la salud y de la educación de los trabajadores y sus familias o el impulso brindado a las actividades recreativas, habrían sido algunas de las herramientas puestas en práctica para generar una cultura socio-laboral acorde con los intereses patronales. Pero si la mirada se centra en la agencia de sus destinatarios, es factible conjeturar también que en el trazado de estas políticas y en los límites de las expectativas de las dirigencias empresariales incidieron demandas por derechos labradas por esos obreros y sus familias en base a sus propias expectativas e intereses, en aquello que consideraron justo para sus vidas. Es en esa labranza donde se inscribe la huelga originada en COMFERPET el 24 de febrero de 1932.

El motivo inmediato de la protesta fue la decisión del capataz de la sección Destilería de despedir a 7 trabajadores sin que mediara causa alguna, cuestión que conllevaba la obligación de abandonar inmediatamente las viviendas. ${ }^{10}$ Por tanto, esa resolución involucraba no sólo la pérdida del ingreso salarial sino también del conjunto de beneficios sociales que colaboraban en la reproducción y el cuidado de la familia proletaria, situación más grave aún dado el contexto económico recesivo. El fracaso de los intentos por revertir tal decisión mediante la negociación condujo a la convocatoria de una asamblea que en la noche del 23 de febrero resolvió el paro. La reincorporación de las personas despedidas a sus puestos de trabajo y el "despido del capataz causante del conflicto"11 figuraron entre las primeras exigencias de los huelguistas, explicitadas en un pliego de condiciones que "una comisión de esposas de obreros" procuró presentar, aunque sin suerte, a los administradores de la compañía al poco tiempo de iniciada la medida de fuerza ${ }^{12}$.

Con el correr de los días, se sumaron a estas demandas la habilitación de una ambulancia por parte de la empresa, la expulsión del médico de la compañía y su reemplazo por uno "competente", el "30 \% de aumento en los jornales", la libertad

\footnotetext{
${ }^{9}$ Una descripción más detallada de este campamento puede consultarse en María Teresa Dittler. Pozos. Kilómetro 8. Un pueblo petrolero de la Patagonia. Buenos Aires, Ediciones Vela al Viento/Ediciones Patagónicas, 2011.

${ }^{10}$ El Chubut, 24 de febrero de 1932.

${ }^{11}$ El Chubut, 24 de febrero de 1932.

${ }^{12}$ El Chubut, 27 de febrero de 1932.
} 


\section{En demanda de lo justo: conflictos por lo justo en la Patagonia petrolera}

de los detenidos por la policía y la "expulsión de los que traicionaron el paro", el pago de salarios íntegros en caso de accidentes laborales, la provisión de ropa, guantes y botas en cantidades suficientes para los obreros, y el reconocimiento de la UGOP, una naciente organización sindical de filiación comunista que desde la clandestinidad había declarado la huelga. ${ }^{13}$

El conflicto amplió sus alcances con la adhesión de los trabajadores de Diadema, Manantial Rosales y del pueblo, quienes llevaron a cabo un paro de 48 horas en solidaridad con los obreros de COMFERPET durante el $1^{\circ}$ y el 2 de marzo. ${ }^{14}$ Además, contó con la organización de mitines y movilizaciones en la localidad de Comodoro Rivadavia, algunas de las cuales estuvieron encabezadas por "mujeres obreras con sus respectivos hijos"15. A pesar de estas demostraciones, la protesta no logró sus objetivos y a su derrota le siguieron detenciones y deportaciones de muchos de los señalados como los "agitadores", y el allanamiento de viviendas y espacios de reunión.

De todos modos, el revés sufrido no evitó una segunda huelga que comenzó en la madrugada del domingo 10 de abril en la empresa Diadema Argentina. ${ }^{16}$ Las exigencias que la ocasionaron comprendieron nuevamente el reconocimiento de la UGOP, la readmisión de todos los obreros despedidos en el conflicto anterior, aumentos salariales, el cumplimiento de la jornada laboral de 8 horas, "la anulación del trabajo extra y cuando sea este realizado por causas indispensables se abonará el 100 por ciento", la prohibición de contratar a obreros y empleados que no formaran parte de la organización sindical, el establecimiento de un límite habitacional de dos personas por pieza, la ampliación del hospital, la habilitación de una escuela, la ampliación de baños y lavaderos para el personal, la anulación de las concesiones otorgadas para las gamelas y la entrega de estas a los obreros para su administración. ${ }^{17} \mathrm{El}$ paro se extendió rápidamente a las restantes empresas, exceptuando YPF y ASTRA, y estuvo jalonado por duros enfrentamientos con "crumiros" o rompehuelgas, y policías. La muerte de Esteban Dohotari, un obrero rumano, perpetrada el 15 de abril durante uno de estos choques por el disparo de un policía que custodiaba el campamento de Diadema, "enardeció los ánimos de los trabajadores"18 conduciendo a que la huelga se volviera general al acatarse la convocatoria de la Unión Gremial de los Obreros del Pueblo, otra organización sindical dirigida por un trabajador comunista de origen italiano, Mario D' Arco.

La reacción ante la magnitud que estaba ganando el conflicto parecía inclinarse hacia el ejercicio de la represión estatal. Así lo indicaba la negativa de las empresas a atender a los representantes de los huelguistas, la presencia frente al

\footnotetext{
${ }^{13}$ El Chubut, 27 de febrero de 1932 y La Vanguardia, 6 de marzo de 1932.

${ }^{14}$ El Chubut, 2 de marzo de 1932.

15 Ibídem.

16 El Chubut, 12 de abril de 1932.

17 Ibídem.

${ }^{18}$ La Protesta, 24 de abril de 1932.
} 


\section{Andrea Andújar}

muelle de YPF desde el 17 de abril del acorazado Mendoza, enviado en "previsión de acontecimientos graves", y la llegada de refuerzos policiales de Rawson, la capital del Territorio. ${ }^{19}$ Ante esa posibilidad, las y los trabajadores ensayaron varias iniciativas. Una de ellas fue la implementada por las mujeres, quienes el 19 de abril en una reunión convocada por el sector femenino del SRI en la que participaron "novias, hermanas, esposas de los huelguistas", decidieron imprimir un volante titulado "¿A quién vas a tirar, hermano?"20. Destinado a los policías, soldados y marineros, su texto sostenía que "no deben de tirar ni un solo tiro contra sus hermanos de clase" y los exhortaba a rebelarse contra las órdenes de sus superiores pues "deben negarse a hacer correr sangre proletaria"21. Bajo serios riesgos, "las esposas de los petroleros" repartieron el panfleto en cuanto puesto de hombres uniformados encontraron, en las empresas, en los negocios y entre "los campesinos cercanos a Comodoro". Pero no sólo ellas. También se sumaron a la actividad disuasiva aquellas que trabajaban en "las casas de tolerancia" del pueblo frecuentadas tanto por trabajadores como por soldados y marineros ${ }^{22}$. Estas acciones se indexaron a los empeños puestos en la recolección de víveres y abrigo para los huelguistas, en el sostenimiento de piquetes montados en las cercanías de los lugares de trabajo e incluso, en la presencia como oradoras en actos como el del

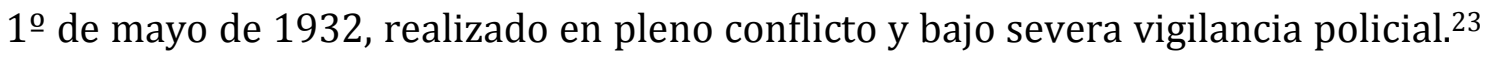
De todos modos, la huelga fue violentamente enfrentada. Y aún cuando continuó algunas semanas más, el 19 de mayo ${ }^{24}$ fue levantada dejando un duro saldo para los trabajadores pues "más de mil (...) fueron deportados, mil novecientos encarcelados, dos mil quinientos desalojados de cinco campos petroleros, dos compañeros desaparecieron, uno fue asesinado y más de dos mil torturados". ${ }^{25}$

Hasta la actualidad, estos conflictos han sido analizados como el fruto de la propagación de la militancia comunista en la zona, explicada o bien como consecuencia de la mixtura entre el impacto local de la gran depresión y la llegada de inmigrantes del este europeo ${ }^{26}$ o bien como deriva de una decisión de la dirección central del Partido Comunista. Embarcada desde mediados de la década de 1920 en la estrategia de enfrentamiento de clase contra clase y convencida de la inminencia del derrumbe del sistema burgués a partir de los alcances de la gran depresión, la dirigencia comunista impelía a redoblar esfuerzos para lograr la proletarización del partido y el fortalecimiento de las estructuras partidarias, la organización de sindicatos únicos por ramas de industria y la agitación de la combatividad obrera mediante el estímulo de diversas luchas. Las huelgas de

\footnotetext{
${ }^{19}$ El Chubut, 19 de abril de 1932.

${ }^{20}$ Rufino Gómez. Op. cit.

${ }^{21}$ Bandera Roja, 19 de abril de 1932.

22 Rufino Gómez. Op. cit.

23 Bandera Roja, 8 de mayo de 1932.

${ }^{24}$ El Chubut, 20 de mayo de 1932.

25 Rufino Gómez. Op. cit; [pág. 67]. Bastardilla en el original.

${ }^{26}$ Nicolás Gadano. Historia del petróleo en Argentina, 1907-1955: desde los inicios hasta la caída de Perón. Buenos Aires, Edhasa, 2006.
} 


\section{En demanda de lo justo: conflictos por lo justo en la Patagonia petrolera}

Comodoro Rivadavia habrían sido, en tal sentido, un caso representativo de ese diagrama político. 27

Sin desestimar la incidencia del activismo comunista, otras lecturas han recalado en estas protestas acentuando la ausencia de la participación de los obreros de YPF y ASTRA, pese al empeño puesto en ello por los militantes de dicha organización. La explicación de este fenómeno ha resaltado dos aspectos. El primero refiere al éxito de ciertas políticas desplegadas en cada una de estas compañías durante la década de 1920 para contener el malestar obrero. Como ejemplo suelen subrayarse las medidas asumidas en YPF bajo la administración del general Enrique Mosconi (1922-1930), tales como las primas por eficiencia y bonificaciones por antigüedad, paternidad y maternidad otorgadas a aquellos obreros que observaran "buena conducta", la construcción de escuelas tanto para la educación primaria de los y las niñas de las familias trabajadoras como para la capacitación técnica de los obreros y sus hijos mayores, la edificación de un hospital y la provisión de atención médica gratuita a domicilio, la construcción de viviendas de mejor calidad, la instalación de comedores con precios módicos para obreros y empleados, el impulso de la "argentinización"28 de la mano de obra y la imposición de unas relaciones de autoridad que emulaban las propias de la jerarquía militar procurando con ello asimismo, promover la idea de unicidad de intereses de obreros, empleados y patronal tras el nacionalismo petrolero (alentado, entre otros modos, a través de las festividades patrias). Se sostiene entonces, que el despliegue de iniciativas de esta naturaleza habría satisfecho muchas de las exigencias que integraban los pliegos de negociaciones de los huelguistas, disuadiendo por tanto a los obreros de YPF y de ASTRA de involucrarse en los conflictos.

El segundo aspecto atendido remite a la importancia de los mecanismos de control implementados por la dirigencia de YPF sobre los obreros, para lo cual ésta habría contado además con el funcionamiento de una comisaría dentro del yacimiento central. Estrechada a partir del golpe de Estado de 1930 -que llevó además a la renuncia de Enrique Mosconi a la jefatura máxima de la compañía- y en consonancia con el incremento general de la represión hacia la clase

\footnotetext{
27 Hernán Camarero. A la conquista de la clase obrera. Los comunistas y el mundo del trabajo en la Argentina, 1920-1935. Buenos Aires, Siglo XXI, 2007.

28 Esta política consistía en suplantar la mano de obra extranjera mediante la contratación de trabajadores provenientes del noroeste de la Argentina. La expectativa depositada en ella era anular la capacidad reactiva y organizativa obrera, basándose en el supuesto de que la misma se debía a la condición inmigrante de los trabajadores. Véase Daniel Marquez. "Conflicto e intervención estatal en los orígenes de la actividad petrolera en Comodoro Rivadavia"; en Daniel Marquez y Mario Palma Godoy. Distinguir y comprender. Aportes para pensar la sociedad y la cultura en Patagonia. Comodoro Rivadavia, Ediciones Proyección Patagónica, 1995. También Susana Torres. "Huelgas petroleras en Patagonia: Inmigrantes europeos, clase y etnicidad (1917-1933)"; en V Jornadas sobre Colectividades. IDES, Buenos Aires, 26 y 27 de octubre de 1995.
} 


\section{Andrea Andújar}

trabajadora y hacia los comunistas especialmente, esa vigilancia habría obturado el desencadenamiento de la huelga en los yacimientos fiscales. ${ }^{29}$

Las interpretaciones que atribuyen al Partido Comunista un rol protagónico en estas huelgas o que calibran los diferenciales impactos de las mismas a partir de la eficacia de los dispositivos patronales, se documentan en acervos documentales variados. Entre ellos, la prensa político partidaria y sindical de la época, los recuerdos de Rufino Gómez -un experimentado comunista cordobés llegado a Comodoro Rivadavia a comienzos de los años treinta-, las obras escritas por Enrique Mosconi, los informes anuales elevados por la dirigencia de YPF al ministerio de Agricultura de la Nación, las notas que circulaban entre las patronales empresariales privadas y estatales, entre estas últimas y las autoridades políticas del Territorio, y las crónicas de los periódicos locales sobre el devenir de los conflictos.

Sin embargo, estas mismas fuentes y los indicios que proveen, estimulan el examen de las protestas bajo otras coordenadas analíticas. En principio, porque revelan la heterogeneidad de sujetos que las dinamizaron. Las noticias periodísticas y las memorias de Rufino Gómez, por ejemplo, permiten advertir que sus protagonistas no fueron solamente los varones ligados al trabajo petrolero sino también las mujeres. Ellas participaron de los intentos por negociar con las patronales y para evitar las represiones, estuvieron con sus hijos en las movilizaciones, tomaron la palabra en los actos obreros y terciaron para liberar a los detenidos. Esa activa presencia femenina constata, como fue formulado en la reconstrucción de la gran huelga ferroviaria de 1917, que la preponderancia masculina en el espacio productivo no se refleja especularmente en el momento del conflicto. ${ }^{30} \mathrm{E}$ invita a explorar, a su vez, de qué manera y en qué medida esas mujeres diversas -pues las había casadas y solteras, madres e hijas, algunas tal vez comunistas y otras sin adscripción política partidaria, "obreras" y trabajadoras del sexo- incidieron en la formulación de las demandas que dieron origen a esas protestas.

\footnotetext{
${ }^{29}$ Estas interpretaciones son seguidas, entre otros, por SusanaTorres. Op. cit., y Daniel Cabral Marques. "Mundos del trabajo y formas de organización sindical en la Cuenca del Golfo de San Jorge durante la primera mitad del siglo XX: entre la radicalización obrera, el planteo reivindicativo y la articulación con el Estado"; en Avances del Cesor. Año X, N 10. Rosario, ISHIR-CONICET/UNR, 2013. ${ }^{30}$ Esta idea es tributaria de la interpretación de Silvana Palermo sobre la protesta ferroviaria de 1917. Véase Silvana Palermo. "¿Trabajo Masculino, Protesta Femenina? La participación de la mujer en la gran huelga ferroviaria de 1917"; en María Celia Bravo, Fernanda Gil Lozano y Valeria Silvina Pita (comps.). Historia de luchas, resistencias y representaciones. Mujeres en la Argentina, siglos XIX y XX. Tucumán, EDUNT, 2007. Asimismo, durante la primera mitad del siglo XX, otros casos que denotan una elevada presencia femenina en huelgas realizadas en actividades con predominancia de fuerza laboral masculina pueden verse en María Celia Bravo. "Entre la resistencia y el conflicto social. Imágenes de la mujer trabajadora en el área azucarera de Tucumán (1888-1904)"; en María Celia Bravo, Fernanda Gil Lozano y Valeria Silvina Pita (comps.). Op.cit. y en Débora D’Antonio. "Representaciones de género en la huelga de la construcción. Buenos Aires, 1935-1936"; en Fernanda Gil Lozano, Valeria Silvina Pita y María Gabriela Ini (dirs.). Historia de las mujeres en la Argentina. Siglo XX. Buenos Aires, Taurus, 2000; Tomo II.
} 


\section{En demanda de lo justo: conflictos por lo justo en la Patagonia petrolera}

En segundo lugar, porque al distinguir ese involucramiento femenino, tales documentos iluminan los múltiples lugares en los que las mismas se jugaron. Ciertamente las huelgas se situaron en el pozo y en el taller, pero también lo hicieron en la peluquería y en la comisaría, en el prostíbulo y en las gamelas, en las calles del pueblo y en las viviendas del campamento, en suma, en muchos ámbitos en los que esas trabajadoras y trabajadores habitaban y circulaban juntos.

En tercer lugar, porque el detalle brindado sobre las exigencias planteadas en los conflictos posibilita indagar las nociones de justicia que cristalizaron en ellas y rastrear cómo fueron modeladas acorde con la forma en que esos sujetos, varones y mujeres, experimentaron sus condiciones de explotación. En ello desplegaron una agencia que contuvo las formas de percibir el mundo y su lugar en él, y que transmutó en tradiciones, cultura e identidades de clase. Pero eso fue parte de un proceso histórico que no comenzó con las huelgas de 1932, aun cuando ellas permitieron ahondar la identificación de intereses comunes. De hecho, muchas de las demandas esgrimidas en esos momentos estaban presentes, como se verá luego, en conflictos desatados durante la segunda mitad de la década de 1910 y la primera de la de 1920. También pueden advertirse en 1932 ecos de formas de organización que habían emergido con anterioridad. Estos antecedentes vuelven factible interpretar tales protestas como un momento de condensación de esas experiencias pretéritas y aventurar que el surgimiento de organizaciones como la UGOP habría sido el resultado no sólo de las voluntades de un partido político sino también y fundamentalmente, de los nexos con una tradición obrera previa.

Un último motivo se encuentra en los indicios de resistencias veladas aquellas puestas en escena justamente cuando un enfrentamiento abierto es percibido como imposible-31 y de actitudes indóciles que aparecen como individuales, llevadas a cabo por fuera de un colectivo organizado explícitamente identificable. Estas pistas se filtran entre los relatos periodísticos y en las narrativas empresariales que daban cuenta de las represiones y su efectividad para acallar las protestas o evitar su propagación a empresas como YPF. Se detectan en los partes diarios de la guardia policial de la comisaría que contenían los nombres de los detenidos y los lugares donde se efectuaba la detención. También, en los listados de los jugadores que integraban los equipos de fútbol de los campamentos petroleros.

En suma, los detalles proporcionados por esas fuentes invitan a pensar las huelgas de 1932 y sus instancias organizativas como un momento de inflexión de una experiencia de clase urdida en femenino y en masculino, históricamente y en múltiples espacios. Se trató de un instante singular en la lucha de clases donde cristalizaron nociones de lo justo que expresadas en términos propios, tensionaron los límites de las relaciones de explotación capitalistas mediante prácticas colectivas e individuales, visibles y ocultadas a los ojos del patrón. De ello buscará dar cuenta más detenidamente el próximo apartado.

${ }^{31}$ James Scott. Los dominados y el arte de la resistencia. México DF, Era, 2000. 


\section{Andrea Andújar}

\section{Las nociones de lo justo}

Los motivos de las huelgas de 1932 enlazaban asuntos relativos al orden de la producción y reproducción de la vida material así como de la organización, la solidaridad, la cultura e identidades proletarias. En torno a esos temas giraban las nociones sobre lo justo que sustentaban las demandas por derechos esgrimidas en tales conflictos. Especialmente, éstas se conjugaban alrededor de tres cuestiones: las referidas a las condiciones de trabajo y de vida, las relativas al control del tiempo laboral y del tiempo libre, y finalmente, el reconocimiento y respeto de la organización proletaria.

En la primera de ellas estaban comprendidas exigencias tales como el aumento de jornales, la provisión de elementos de vestimenta necesarios para el cumplimiento de la labor productiva, el acceso al resarcimiento monetario por accidentes de trabajo, el mejoramiento de la prestación habitacional, sanitaria y educativa por parte de las empresas. Esas demandas involucraban no sólo la cotidianeidad del obrero sino también del hogar proletario pues era el presupuesto destinado a solventar a la familia el que se veía mermado por los bajos salarios, los gastos en el atuendo para el trabajo o la atención deficitaria de la salud y de la educación.

La segunda cuestión incluía la reivindicación del cumplimiento de las 8 horas de trabajo y la anulación de las horas extras o en su defecto y cuando fuera "indispensable", realizarlas a cambio del abono del 100\% del jornal. Esto aunaba al menos dos horizontes. El primero residía en disminuir unas extensas jornadas laborales que comúnmente promediaban las doce horas y con ello, el desgate físico que el trabajo petrolero traía aparejado. El segundo consistía en contar con mayor tiempo libre para hacer lo que se deseara, ya fuera descansar, recrearse e incluso, participar de las veladas cinematográficas, de los picnics o las reuniones políticas promovidas por organizaciones tales como el Partido Comunista.

La última contemplaba el reconocimiento de la UGOP y por tanto, del legítimo derecho de contar con un sindicato que defendiera los intereses de la clase trabajadora, colocando bajo su órbita además, la potestad de decidir quiénes formaban parte de ese colectivo en el ámbito de trabajo. En esos términos se sustentaba la exigencia sobre la intervención sindical para las futuras contrataciones de obreros y empleados en las empresas. Pero también, la de "expulsar" a quienes hubieran traicionado el paro. Reservarse para sí, a través del sindicato, la posibilidad de arbitrar en los contratos procuraba entonces un reaseguro, el de evitar que quienes ingresaran a cubrir puestos en las empresas fueran contrarios a los intereses de los trabajadores petroleros en tanto tales. A su vez, encerraba otra implicancia: que las definiciones en torno a la identidad obrera no se correspondían solamente con la relación con los medios de producción sino también con la conciencia de clase. Era en ella donde se ubicaba uno de los puntales de la solidaridad proletaria al reclamarse la liberación de los detenidos y 


\section{En demanda de lo justo: conflictos por lo justo en la Patagonia petrolera}

la reincorporación de quienes hubieran sido despedidos por su participación en los conflictos o sin que mediara otra causa que la decisión de un capataz.

Muchas de estas reivindicaciones no eran una novedad para 1932. Algunas como el aumento de salarios, la reducción de la jornada laboral a 8 horas, el pago de horas extras o la mejoría de las condiciones de vivienda y de salud tenían larga data. Habían estado presentes entre las razones que desataron la mayoría de las huelgas petroleras ocurridas entre los años 1917 y 1922. Protagonizadas tanto por los obreros de las compañías privadas como por los del yacimiento estatal, el decurso de esas protestas había dado lugar además, al surgimiento de una organización sindical, la Federación Obrera Petrolífera (FOP).

Creado durante un prolongado conflicto ocurrido hacia fines del segundo semestre de 1917, este agrupamiento de corte anarco-sindicalista, que nucleaba a los trabajadores del pueblo, a los ferroviarios y a los petroleros, explicitaba en uno de los artículos de su estatuto fundacional que "No podrán formar parte de esta Federación, autoridades, patrones o directores de trabajo". 32 Esta expresión establecía unos límites que contribuían a la conformación de una identidad proletaria clasista, dispuesta a confrontar con sus adversarios para "defender y mejorar las condiciones económicas, morales, sociales, técnicas e intelectuales de todos sus federados" y "estrechar las relaciones de los obreros en general" a los fines de avanzar en la "emancipación de la clase obrera". ${ }^{33}$ Organizada en seccionales que eran fiscalizadas por un Comité Central, la FOP contaba además con la edición de El obrero petrolífero, un periódico dedicado a la difusión de su ideario así como de aquellas cuestiones relativas a los problemas y la organización obrera petrolera de Comodoro Rivadavia.

La presencia de esta corriente política en los campamentos fue notoria hasta 1922. A partir de entonces, con el ascenso de Mosconi a la dirección de YPF, encontró dificultades variadas para resistir la profundización de los embates en su contra dispuestos por las compañías petroleras. De todos modos, su existencia ostensible hasta el año 1927-,34 las formas de organización y las huelgas que impulsó, evidencian que lejos de actuar en campo yermo, la UGOP -y el propio Partido Comunista- se insertó en una trayectoria política obrera abonada con

\footnotetext{
32 Artículo 17 del Estatuto fundacional de la FOP del 20 de noviembre de 1917, citado en Daniel Marquez y Mario Palma Godoy. Comodoro Rivadavia en tiempos de cambio. Una propuesta para la revalorización de nuestras identidades culturales. Comodoro Rivadavia, Ediciones Proyección Patagónica, 1993; [pág. 55].

33 Las aseveraciones entrecomilladas corresponden al Artículo 1, Inciso a, y al Artículo 3 respectivamente del mencionado estatuto. Citado en Daniel Marquez y Mario Palma Godoy. Comodoro Rivadavia en tiempos de .... Op. cit; [pág. 54].

${ }^{34}$ En 1924, a pesar de los empeños puestos por Mosconi para desterrar la influencia anarquista por medio de prohibiciones al funcionamiento de organizaciones sindicales, detenciones y deportaciones de obreros vinculados con esta corriente, y la aceptación de algunas demandas obreras a través de la implementación de políticas de corte asistencialista, la FOP logró reorganizarse y liderar dos conflictos: uno como parte de una huelga nacional contra la ley de jubilaciones recientemente sancionada y el segundo, contra las detenciones y deportaciones de obreros dispuesta por la dirigencia de YPF. En 1927 también impulsó una protesta en repudio del asesinato de Sacco y Vanzetti. Sobre estos conflictos véase Susana Torres. Op. cit.
} 


\section{Andrea Andújar}

anterioridad y que las demandas expresadas en las protestas de 1932 se inscribían en una experiencia que venía demarcando la arena de la lucha de clases desde hacía más de una década.

Esa arena, por otra parte, también estaba tallada por la invocación de derechos consagrados institucionalmente, esto es, la ley. Tal instrumento ha sido visto como uno de los mecanismos de dominación burguesa en tanto regulador y garante de la reproducción de relaciones basadas en la desigualdad y la opresión. Pero como lo ha planteado ya E. P. Thompson y retomado Carolyn Steedman, entre otras historiadoras sociales, esta expresión del derecho es más que eso o al menos, no es sólo eso. Es además parte de la lucha de clases y como tal, proporciona un terreno donde se definen y confrontan nociones alternativas sobre la ley y sus usos. ${ }^{35}$ En ese sentido, acudir a ella fue una de las estrategias que puso en práctica la clase obrera petrolera durante los conflictos de 1932 para intentar volcar ciertas situaciones a su favor. El reclamo por el cumplimiento de la normativa sobre accidentes de trabajo brinda un ejemplo.

Una investigación que rastrea las demandas judiciales iniciadas por ciertos trabajadores o sus familias entre los años 1907 y 1915 para obtener una indemnización por los daños sufridos en accidentes laborales, revela cómo esas demandas, los fallos y debates que generaron, incidieron en la sanción de la ley de accidentes de trabajo en 1915. ${ }^{36}$ Los alcances de la misma fueron materia de discusiones parlamentarias y la redacción finalmente aprobada no conformó del todo a quienes apoyaban la iniciativa, como la bancada socialista. ${ }^{37}$ De todos modos, el texto sancionado establecía un piso de derechos que habilitaba a su vez, nuevos reclamos. Uno de ellos era el de hacerlo cumplir. En esa acción se embarcaron los obreros petroleros de Comodoro Rivadavia, sumidos en los riesgos que implicaban las tareas desempeñadas en los pozos de perforación y extracción o las enfermedades que los acechaban producto de las inclemencias climáticas, las condiciones de vivienda y los largos recorridos que debían realizar para llegar al lugar de trabajo. Sobre esto último, por ejemplo, el periódico sindical comunista $E l$ obrero petrolero denunciaba que entre "las herejías que se cometen" contra los obreros en YPF, estaba la de tener que levantarse a las 5:30 hs de la mañana para "ir a pié 7, 9 hasta 10 kilómetros a trabajar bajo la lluvia, nieves, vientos y fríos por

\footnotetext{
35 Véase Edward P. Thompson. Op. Cit; [pág. 119]. También, su célebre estudio Los orígenes de la Ley Negra. Un episodio de la historia criminal inglesa. Buenos Aires, Siglo XXI, 2010. Para un trabajo donde la historiadora británica retoma este aspecto del planteo thompsoniano, puede consultarse Carolyn Steedman. "At Every Bloody Level: A Magistrate, a Framework-Knitter, and the Law"; en Law and History Review. The American Society for Legal History, Vol. 30, № 2, May 2012.

36 Véase en este mismo dossier, Florencia D'Uva. "En reclamo de un resarcimiento: trabajadores y accidentes de trabajo en Buenos Aires (1900-1915)". Para una visión que se sitúa en las iniciativas estatales, véase Karina Ramacciotti. "De la culpa al seguro. La Ley de Accidentes de Trabajo, Argentina (1915-1955)"; en Mundos do Trabalho, № 3, 2011.

${ }^{37}$ El articulado de esta ley así como los debates que precedieron su sanción se encuentran disponibles on line. Véase: http://www1.hcdn.gov.ar/dependencias/dip/wdebates/Ley.09688.Debate.Accidentes.de.Trabajo.p $\underline{\mathrm{df}}$
} 


\section{En demanda de lo justo: conflictos por lo justo en la Patagonia petrolera}

dentro de las matas". ${ }^{38}$ Estas condiciones de trabajo constituían una amenaza cotidiana a la salud y expectativa vital de los trabajadores. Según un estudio basado en el registro de las sepulturas del Cementerio Norte -ubicado entre el campamento central de YPF y el pueblo- y focalizado en el lapso comprendido entre 1918 y 1933, la bronconeumonía, las fracturas de cráneo y de columna vertebral, las hemorragias internas, las lesiones y las quemaduras figuraban entre las principales causas de muerte de los obreros petroleros jóvenes y adultos, mayormente jornaleros. ${ }^{39}$ La dirigencia empresarial usualmente argüía que estos decesos, que correspondían a casi el $50 \%$ del total de los fallecimientos de los trabajadores habitantes en los campamentos, eran fruto del "descuido" de estos últimos. ${ }^{40}$ Lograba así sortear el pago de las indemnizaciones monetarias a las familias de los fallecidos o para aquellos que hubieran quedado inválidos. Por tanto, hacer cumplir la ley invirtiendo la carga de la prueba dependía de la correlación de fuerzas, una correlación que guardaba estrecha relación con la capacidad de acción proletaria. Era esa agencia la que había incidido en el reconocimiento por parte del Estado de la negligencia patronal como una causa posible del accidente laboral. Y era ella, que en la geografía petrolera se expresaba con la huelga, la que podía pujar por el efectivo cumplimiento de ese derecho. De allí su indexación al pliego de condiciones presentadas ante la patronal. Mas esa no fue la única demanda que los trabajadores esgrimieron apelando a la norma. El texto de la ley también fue citado para la defensa de la libertad de acción y la integridad personal durante los conflictos.

Jacinto Ozán había comenzado a trabajar en YPF a fines de la década de 1920. "De nacionalidad Argentino", según sostuvo en una carta publicada por El Chubut, había llegado a Comodoro Rivadavia desde Buenos Aires con la esperanza de encontrar tranquilidad y un trabajo en que el que ganara lo necesario para vivir dignamente. ${ }^{41} \mathrm{Su}$ educación podía darle ciertas ventajas para concretar sus ilusiones. A los 14 años había ingresado en la "Escuela de Mecánicos de la Armada" donde se formó como mecánico aviador, lo cual lo llevó a prestar "servicios en la Base Naval de Aviación" y en "los barcos de guerra". Creía que con esa experiencia conseguiría un puesto bien pago en el yacimiento fiscal como obrero calificado. Sin embargo, las cosas no salieron como esperaba. Las condiciones de trabajo no eran como suponía y tampoco era sencilla la vida en el campamento. Es más, al parecer, los "atropellos que se efectúan en los YPF y en Kilómetro 8 con los obreros de los

38 El Obrero Petrolero, 3 de agosto de 1932, "Carta del Comité Sindical del YPF". Pág. 3. Fondo Documental "Enrique Mosconi. Asuntos de YPF; Personal obrero de Yacimientos Comodoro Rivadavia. Expedientes de la Dirección General". Caja $\mathrm{N}^{\circ}$ 8, Museo del Petróleo, Comodoro Rivadavia.

39 Alejandra Ferreira y Paula Fernández. "Por culpa de cuatro fumadores empedernidos...Condiciones laborales y muertes accidentales en Comodoro Rivadavia 1919-1933"; en I Jornadas de Investigación en Ciencias Sociales. Facultad de Humanidades y Ciencias Sociales, Universidad Nacional de la Patagonia "San Juan Bosco"-Sede Comodoro Rivadavia. 26 a 29 de noviembre de 2007.

40 Ibídem.

${ }^{41}$ El Chubut, 4 de marzo de 1932. 


\section{Andrea Andújar}

mismos", según afirmaba en otra de las cartas enviadas al periódico local, ${ }^{42}$ lo habían llevado a intentar sumarse a la huelga comenzada hacía algunas semanas en COMFERPET. Tal vez por ello, puesto que nunca le aclararon la causa, había sido apresado el 1ํ de marzo y conducido a las "mazmorras de YPF", como denominaba a las celdas de la comisaría del yacimiento. ${ }^{43}$ En ellas permaneció detenido e incomunicado durante tres días, sin comer nada en las primeras 24 horas y durmiendo en el suelo durante todo el tiempo que duró su cautiverio. Cuando recuperó la libertad, envió nuevamente unas líneas a El Chubut donde además de expresar su agradecimiento por la "valiente actitud" del director al dar a publicidad su situación, señalaba que sus días en la cárcel habían sido una "tortura moral (...) quitándonos la libertad, menoscabando nuestros derechos ciudadanos de hombres libres garantizado por una Constitución".44

Aunque no se cuenta con precisiones sobre su fecha de nacimiento, es indudable que en el transcurso de su vida Jacinto vio la ampliación de la ciudadanía política masculina y de su mano, el ascenso del radicalismo al gobierno. No se sabe cómo actuó ante ello. Su condición de nativo le habría dado la oportunidad de votar. Pero si lo hizo y por quién, permanece aún incierto. De todos modos, que Ozán recurriera a un texto y un derecho asimilados a la tradición republicana liberal revela que ésta no era ajena a su cultura política. Mas su pertenencia y experiencia de clase habría revestido de otros sentidos a los términos de esa tradición. En su pluma, la ciudadanía y la Constitución habrían perdido su carácter abstracto para ser puestas en juego en un campo de la arena política que no se demarcaba por la participación electoral sino en el terreno de la contienda de una clase contra otra. Desde allí Jacinto se habría reapropiado de ese derecho y de esa norma para reforzar la legitimidad de su decisión de participar en el enfrentamiento con sus patrones y reclamar en ello el resguardo de su persona en tanto trabajador.

Ahora bien, Jacinto no fue el único obrero de YPF encarcelado a propósito de la huelga iniciada en COMFERPET. Acorde con el libro de partes diarios de la guardia policial de la comisaría emplazada en YPF, varios trabajadores habían sido detenidos "por averiguación" en Villa Rosada y Villa Obrera, dos de los barrios del campamento del yacimiento fiscal. Estos arrestos tenían un carácter preventivo ya que procuraban impedir que la compañía estatal fuera envuelta en el conflicto. Pero además, buscaban identificar a los "agitadores", sospechados de estar ligados al Partido Comunista, a la UGOP o a cualquiera de los restantes frentes de masa comunistas. En ocasiones, los encarcelados eran luego deportados o indexados a "listas negras" confeccionadas por la administración de YPF, una práctica que la

\footnotetext{
42 El Chubut, 5 de marzo de 1932.

43 Parte del servicio de guardia policial de YPF de $1^{\text {o }}$ al 2 de marzo. Folio 164 . Libro de Partes Diarios de la Policía de YPF. Tomo del 9 de octubre de 1931 al 9 de abril de 1932. Museo Histórico Policial de Rawson, Chubut.

${ }^{44}$ El Chubut, 8 de marzo de 1932.
} 
empresa había emprendido en la década anterior contra los anarquistas. ${ }^{45}$ En otras, salían de la cárcel y no sufrían represalias. Tal fue el caso de Alfredo Raffo, un obrero que jugaba para uno de los equipos de fútbol del campamento del yacimiento fiscal.

Detenido en Villa Obrera y conducido a la comisaría de YPF junto con otros cinco trabajadores en la medianoche del 9 de marzo de 1932, ${ }^{46}$ Raffo permaneció en la cárcel hasta la madrugada siguiente. Cuando salió en libertad, pudo retornar a su puesto de trabajo y continuar jugando para distintos clubes de YPF. ${ }^{47}$ Tal vez las presunciones sobre su participación en el conflicto, que ya estaba diluyéndose, no pudieron comprobarse. 0 quizá, fuera el prestigio obtenido en un deporte apreciado por la dirección de la empresa como un vehículo para tutelar el desarrollo físico y moral del trabajador petrolero, lo que impidió su despido o su expulsión de la zona. ${ }^{48}$

Desde comienzos del siglo XX pero fundamentalmente a partir de la década de 1920, la práctica del fútbol se había ido extendiendo en la Patagonia. El pueblo de Comodoro Rivadavia y los campamentos petroleros adyacentes a su territorio mostraban esa proliferación. Si para 1916, cuando se disputó el primer encuentro oficial de fútbol, existían dos equipos, uno en el pueblo y otro en el campamento de YPF, en los años siguientes surgirían varios más en ambos lugares así como en los asentamientos de COMFERPET y ASTRA. De acuerdo con una reconstrucción de la historia la historia local de este deporte, ese auge se habría debido tanto a los afanes por disciplinar y moralizar a determinados sectores sociales a la par que argentinizar un territorio débilmente vinculado con resto de la Nación, como a la explosión de una práctica asociacionista que encontraba en los clubes un canal de participación comunitaria democrática. En tal sentido, el fútbol, al igual que otras actividades relativas al uso del tiempo libre por parte de los trabajadores, habría sido un ámbito de intervención de las dirigencias empresariales para intentar

\footnotetext{
45 Así sucedió con Jacinto Ozán e Ignacio González, uno de sus compañeros de celda, deportados el 19 de marzo de 1932. Parte del servicio de guardia policial de YPF del 19 de marzo. Folio 181. Libro de Partes Diarios de la Policía de YPF. Tomo del 9 de octubre de 1931 al 9 de abril de 1932. Museo Histórico Policial de Rawson, Chubut. Asimismo, una nota elevada por el Director General de YPF, Mario Silveyra, al ministro de Agricultura De Tomaso el 31 de agosto de 1932 advirtiendo sobre el peligro de las actividades comunistas en el yacimiento, anexaba un listado de "indeseables" que habían sido expulsados de la zona y que se encontraban nuevamente en Comodoro Rivadavia. Fondo Documental "Enrique Mosconi. Asuntos de YPF; Personal obrero de Yacimientos Comodoro Rivadavia. Expedientes de la Dirección General". Caja Nº 8. Folios A 2.16, 2.17, 2.18 y 2.19. Museo del Petróleo, Comodoro Rivadavia.

46 Parte del servicio de guardia policial de YPF del 9 a al 10 de marzo. Folios 172 y 173 . Libro de Partes Diarios de la Policía de YPF. Tomo del 9 de octubre de 1931 al 9 de abril de 1932. Museo Histórico Policial de Rawson, Chubut.

$47 \mathrm{Su}$ nombre y apellido aparecían en el listado de jugadores que integraban el "Team del Yacimiento", mencionado por el diario El Chubut en su sección "Vida en los Campamentos Petroleros". Luego, en abril, fue incorporado a otro club, el Florentino Ameghino. Véase respectivamente El Chubut, 2 de febrero y 12 de abril de 1932.

48 Esta idea retoma el planteo de José Sergio Leite López en torno a la aparición de la figura el jugador operario en una fábrica carioca a comienzos del siglo XX. Véase José Sergio Leite López. "Classe, etnicidade e cor na formação do futebol brasileiro"; en Claudio Batalha, Fernando Teixeira da Silva y Aelxandre Fortes (orgs.). Culturas de Clase. Sao Paulo, Unicamp, 2004.
} 


\section{Andrea Andújar}

modelar la conducta de aquellos; pero también, un espacio de sociabilidad que brindó a obreros y empleados la posibilidad de fortalecer su identidad sociolaboral y hallar ciertas grietas desde las que resistir tales intentos. ${ }^{49}$ Este último aspecto, según lo ha reseñado otro estudio, podía observarse plenamente en YPF bajo la égida de Mosconi pues ese espacio recreativo habría posibilitado el ejercicio de una resistencia simbólica de los trabajadores en momentos donde articular otras formas de organización, tales como los sindicatos, era dificultoso. ${ }^{50}$ Es factible considerar que en el contexto de 1932, donde el control sobre los obreros de esa compañía se habría estrechado, los encuentros futbolísticos seguían proporcionando la oportunidad de discutir cuestiones como la huelga desatada en febrero, informarse sobre lo que iba sucediendo con ella y sopesar si involucrarse o no pues permitían guardar las apariencias ante la vigilancia de los policías que rondaban los campos de juego o de los capataces y directivos que pudieran asistir a tales eventos.

Otras actividades llevadas a cabo fuera del horario de trabajo también alentaban el intercambio de novedades e ideas, y viabilizaban la consolidación de vínculos entre los y las trabajadoras que daban vida a esas comunidades obreras. Tal era el caso de los picnics, las fiestas y las veladas culturales, espacios de reunión cuyos sentidos y finalidades se encontraban también atravesados por la disputa política. Así, por ejemplo, además de las festividades relativas a las conmemoraciones de fechas patrias, YPF solía patrocinar excusiones con almuerzos al aire libre, representaciones teatrales y funciones musicales para los y las trabajadoras y sus familias. Otro tanto hacía el Partido Comunista con sus veladas cinematográficas en el Rex, un cine habilitado en el pueblo en 1931, cuando invitaba a asistir a las proyecciones de películas tales como La Tempestad amarilla o Sacco y Vanzetti, seguidas por conferencias sobre temas tales como la revolución bolchevique, la España republicana, la situación obrera local e internacional o el estado de las "fuerzas de la reacción" a nivel mundial. 510 con los picnics, organizados para estrechar relaciones de camaradería, recaudar fondos para sufragar gastos de imprenta, actos como el del $1^{\circ}$ de Mayo o para la ayuda a los presos, entre otras cuestiones, ${ }^{52}$ y discutir sobre las condiciones laborales, las demandas que se elevarían a las empresas y los lineamientos a seguir para ello. No era tarea sencilla "burlar la vigilancia policial para evitar una caída en masa", según

\footnotetext{
${ }^{49}$ Gabriel Carrizo. "Los trabajadores y su tiempo libre. El fútbol en las comunidades obreras de Comodoro Rivadavia durante las primeras décadas del siglo XX"; en Segundas Jornadas de Historia de la Patagonia. Universidad Nacional del Comahue 2, 3 y 4 de noviembre, 2006.

50 Edda Lía Crespo. "De Germinal a Florentino Ameghino. Memoria, política y asociacionismo en Comodoro Rivadavia (1919-1923)"; en Entrepasados, Año X, № 20/21, 2001.

${ }^{51}$ Las referencias a estas proyecciones cinematográficas aparecen respectivamente en Rufino Gómez. Op. cit.; [pág. 72] y en "Volante de la UGOP". Sin folio. Fondo Documental "Enrique Mosconi. Asuntos de YPF; Personal obrero de Yacimientos Comodoro Rivadavia. Expedientes de la Dirección General". Caja $\mathrm{N}^{\circ}$ 8, Museo del Petróleo, Comodoro Rivadavia.

${ }^{52}$ Esta información proviene del balance de entradas y salidas de dinero publicado en un recuadro por El obrero Petrolero. 3 de agosto de 1932; [pág. 4]. Fondo Documental "Enrique Mosconi. Asuntos de YPF; Personal obrero de Yacimientos Comodoro Rivadavia. Expedientes de la Dirección General". Caja Nº 8, Museo del Petróleo, Comodoro Rivadavia.
} 


\section{En demanda de lo justo: conflictos por lo justo en la Patagonia petrolera}

relatara Rufino Gómez. ${ }^{53}$ Tampoco habrá sido fácil para las compañías evitar que los y las activistas obreras, ligadas o no al Partido Comunista, acudieran a las actividades recreativas impulsadas por ellas. Lo cierto es que, como ya se advirtió para el caso de los y las trabajadoras de Buenos Aires en las primeras décadas del siglo pasado, este tipo de actividades, aún cuando sujetas a pugnas políticas, implicaron formas de participación que colaboraron en edificar "un lenguaje de derechos"54 que en Comodoro Rivadavia, sometió a debate y tensionó los límites de lo aceptable en las condiciones de explotación.

En síntesis, los encuentros futbolísticos, las festividades, los picnis y las veladas culturales, entre otros espacios y formas de encuentro vinculadas con el uso del tiempo libre, proporcionan un punto de mira privilegiado para captar la urdimbre de las huelgas y percibir cómo las demandas y las nociones de justicia que las atravesaron se edificaron no sólo en el lugar de trabajo y de la organización sindical y política, sino también en una trama de redes de sociabilidad que lo excedían. Que las mujeres formaran parte de tal trama permite conjeturar asimismo, sobre la manera en que terciaron en esa edificación y en ese lenguaje de derechos.

Ante todo, el estar allí, participando de esos ámbitos colectivos que hacían a los momentos de esparcimiento, les posibilitaba compartir entre ellas y con otros varones lo que pasaba en sus hogares y en el trabajo, intercambiar opiniones, descubrir intereses comunes y discutir maneras de actuar ante determinadas situaciones que las afectaban a ellas o a su comunidad. Esos encuentros y diálogos marcaron su involucramiento en las huelgas justamente porque los intereses que enlazaban a tales mujeres en razón de su clase y su género no eran ajenos a los motivos que las desataron. Las exigencias relativas al aumento salarial y al mejoramiento de las prestaciones de salud, por ejemplo, impactaban de manera directa en el bienestar de sus hogares, bienestar del que ellas eran responsables en su rol de garantes del cuidado y la reproducción de sus familias. ${ }^{55}$ También en tanto sostén de sí mismas, si eran solteras, o de sus hijos e hijas, si habían enviudado y tenían criaturas a su cargo. Así había ocurrido con Carmen Fernández, una mujer que había comenzado a trabajar para YPF en noviembre de 1926 luego de la muerte de su marido, Julio Montoya. El jornal diario que percibía por atender el baño entre diez y doce horas, y mantenerlo limpio era alrededor de $\$ 3,50$, dos pesos menos que lo ganado por un operario petrolero no calificado. Con ese dinero debía arreglárselas para sustentarse a sí misma y a sus tres hijos, Julio, Carmen y

\footnotetext{
53 Rufino Gómez. Ob. cit.; [pág. 34].

54 Véase Mirta Z. Lobato y Silvana Palermo. "Del trabajo a las calles: dignidad, respeto y derechos para las y los trabajadores"; en Mirta Z. Lobato (ed.). Buenos Aires. Manifestaciones, fiestas y rituales en el siglo XX. Buenos Aires, Editorial Biblos, 2011; [pág. 74].

55 Temma Kaplan. "Conciencia femenina y acción colectiva: el caso de Barcelona, 1910-1918”; en J. Amelong y M. Nash (comps.). Historia y género: las mujeres en la Europa moderna y contemporánea. Valencia, Alfonso el Magnánimo, 1990.
} 


\section{Andrea Andújar}

Dionisio. ${ }^{56}$ No se cuenta actualmente con datos más precisos sobre el jornal de otras labores o relativos a las empresas implicadas en los conflictos. Sin embargo, un volante aparecido en 1933 y firmado por la "Agrupación Femenina", una organización presumiblemente ligada al Partido Comunista, permite vislumbrar la situación por la que atravesaban algunas de las mujeres que trabajaban como asalariadas en los campamentos. El texto sostenía que:

El hambre y la miseria azota a nuestros hogares (...), las sirvientas, mucamas, cocineras y lavanderas, somos sometidas cada vez a una explotación mas bestial, trabajamos 14 y 16 horas por dia, ganado un sueldo de hambre de 30 pesos por mes que no nos alcanza ni para el alquiler, para nosotras no hay un dia de descanso en la semana despues de sacarnos el "jugo" desde las 7 de la mañana hasta las 10 de la noche, los domingos tenemos que quedarnos a cuidar a los hijos de nuestros explotadores, mientras se van a divertir en los vailes o á emborracharse con Champan en el Club Social."57

A partir de estas líneas es factible inferir que no existían amplias variaciones entre las empresas en cuanto a lo pagado por este tipo de labores. Pero además, el volante denota que lo percibido a cambio de unas jornadas laborales que eran tan largas como las de los varones, tornaba dificultoso el mantenimiento de la familia. Tales condiciones habrían redundado en la determinación de muchas mujeres de plegarse a las huelgas, fuera como asalariadas o como esposas de los trabajadores petroleros.

También las convocaban las implicancias aparejadas a la pérdida de la fuente laboral de sus esposos, las cuales no se restringían solamente a la merma del ingreso familiar. Como se señaló anteriormente, los despidos de los trabajadores eran seguidos por el desalojo de las viviendas, cuestión que empeoraba más aún las cosas en un contexto marcado por los efectos de la crisis mundial. Por otro lado, si el despido había estado motivado por el conflicto o por sospechas sobre el activismo político y sindical de los trabajadores, el panorama podía complicarse todavía más. Terminar en la cárcel o en una "lista negra" no era un destino poco probable. Cartas como las de B. Rey o de Jacinto Ozán, además, daban cuenta del tipo de trato que recibían los detenidos en la comisaría del pueblo o de YPF. Pero también, se temía que pudiesen ser deportados. Era un miedo fundado a juzgar por las noticias publicadas durante los primeros días de la huelga iniciada en COMFERPET en las que se consignaba que las "autoridades policiales habrían embarcado en el buque petrolero Ameghino a un contingente de obreros" y que era "una práctica habitual deportar sin dejar rastros". ${ }^{58}$ A su vez, las expulsiones de trabajadores considerados indeseables estaban presentes en la memoria del pasado cercano de esas comunidades ya que los cuadros directivos de la petrolera

\footnotetext{
56 Ficha de Carmen Fernández, viuda de Julio Montoya. Fichas del personal de YPF. Archivo personal de Susana Torres. Comodoro Rivadavia.

57 Expediente 474-4971-1933-11-13. Archivo Histórico Provincial de Rawson.

58 El Chubut, 28 de febrero de 1932.
} 


\section{En demanda de lo justo: conflictos por lo justo en la Patagonia petrolera}

estatal las habían implementado a propósito de las protestas obreras ocurridas a fines de la década de 1910 y a comienzos de la siguiente.

Por tanto, las razones que llevaron a las mujeres a intervenir en estos conflictos habrían combinado diversas cuestiones relativas a la defensa del hogar proletario y que comprendían desde su acuerdo con la justicia de los reclamos esgrimidos en ellos hasta el resguardo de la integridad de los trabajadores que aparecían como sus protagonistas y que no eran otros que sus maridos, hermanos, novios, padres e hijos. Podría concluirse, entonces, que ese agenciamiento femenino no cuestionaba las relaciones de género o, lo que es lo mismo, el lugar subordinado y dependiente que la división sexual del trabajo social les asignaba en tanto esposas y madres. De hecho, era así como generalmente aparecían nombradas en la prensa local y partidaria, o en las memorias de Rufino Gómez. Sin embargo, esas acciones encaradas por las mujeres en el terreno público y político, también tensionaron ciertas aristas de las relaciones de poder y lo esperado de su sexo. Si sus nociones de justicia se imbricaban con garantizar el cuidado y la reproducción de sus familias, esgrimir su defensa implicó traspasar las puertas de sus hogares ocupando con actitudes inesperadas escenas supuestamente reservadas para los varones. Tal vez apelar a ciertos estereotipos sobre sus roles en la comunidad fue parte de una estrategia propia para intentar torcer complejas situaciones a su favor o mitigar posibles represalias. Quizá no y tampoco es fácil establecerlo. Pero en la base de sus actos operó la politización de sus vínculos cotidianos así como una lectura política de la realidad que anclaba en su clase y en su género. De allí que se presentaran en las comisarías a fin de lograr la libertad de los detenidos, dieran la cara ante los administradores de la compañía intentando entregar el pliego de condiciones para levantar la huelga o se sintieran atraídas para participar de espacios tales como el SRI o la "Agrupación Femenina".

En definitiva, esas mujeres y esos varones actuaron, demandaron y se organizaron a partir de su experiencia de clase, una experiencia sexuada que había comenzado a tallarse mucho antes de las huelgas de 1932, que se forjó en múltiples espacios y que enmarcó los sentidos de justicia por los que batallaron quienes entre conflictos y negociaciones, dieron existencia a esas específicas comunidades petroleras.

\section{A modo de cierre}

Este trabajo pretendió realizar un primer acercamiento a la reconstrucción de las nociones de lo justo edificadas por los y las trabajadoras vinculadas con la actividad petrolera en Comodoro Rivadavia. Para ello, concentró su atención en las huelgas de 1932 y en las demandas por derechos esgrimidas en ellas a sabiendas, sin embargo, de que la historia de esas nociones así como la de la propia clase obrera, es mucho más que la de sus abiertas confrontaciones con sus patrones, la sus partidos políticos o la de sus organizaciones sindicales. Es también la historia de dónde y cómo vivían, dormían, se divertían y se educaban las mujeres y los 


\section{Andrea Andújar}

varones trabajadores, cuáles eran sus relaciones, sus acciones cotidianas, sus creencias, aquellas ideas que aceptaban o rechazaban. Justamente por ello, aquí se han situado esos conflictos como la condensación de una experiencia de clase que, atravesada por ciertas concepciones de género, se expresó y recreó en el taller y en la vivienda, en el horario de trabajo y en el del partido de fútbol, en el cine y en las movilizaciones, en suma, en particulares espacios, tradiciones, identidades y culturas proletarias.

Esas nociones de lo justo involucraron la defensa del hogar proletario, el control por parte de los trabajadores del tiempo de labor y del tiempo libre, y el reconocimiento y respeto de la organización obrera. Implicaron, en definitiva, poner en tensión los límites aceptables de las condiciones de explotación redifiniendo también en ello -y a partir de solidaridades y actitudes leídas como traición durante los conflictos- quién formaba parte de esa clase obrera y quién no.

Asimismo, en ocasiones, tales concepciones se expresaron apelando a términos que no se circunscribían exclusivamente a la experiencia política obrera o, mejor dicho, que eran compartidos con otras clases sociales, incluyendo la de sus adversarios. Así fueron invocadas la Constitución y la ciudadanía, la ley y el propio derecho. Mas coincidir en esas palabras no necesariamente fue equivalente a comulgar en sus sentidos. Por el contrario, los significados de la ley y la condición ciudadana, por ejemplo, fueron parte de una arena de disputas cuyas definiciones, límites y alcances estuvieron dados por esa experiencia y pertenencia de clase.

El estudio de esas contiendas por lo justo y los términos y formas en que se expresaron invita a advertir, por último, cómo, desde su particular experiencia, esos trabajadores y trabajadoras abrieron grietas a la dominación de clase y de género en las comunidades petroleras de Comodoro Rivadavia. Comprender más cabalmente cuánto de sus protestas colectivas e individuales, de sus resistencias abiertas y solapadas, de sus vivencias, valores y nociones de justicia obligaron a reformular las herramientas y horizontes de tal dominación en ese entramado histórico, es el desafío que guía la profundización de esta investigación.

\section{Bibliografía de referencia}

Alejandra Ferreira y Paula Fernández. "Por culpa de cuatro fumadores empedernidos...Condiciones laborales y muertes accidentales en Comodoro Rivadavia 1919-1933"; en I Jornadas de Investigación en Ciencias Sociales. Facultad de Humanidades y Ciencias Sociales, Universidad Nacional de la Patagonia "San Juan Bosco"-Sede Comodoro Rivadavia. 26 a 29 de noviembre de 2007.

Carl Solberg. Petróleo y nacionalismo en la Argentina. Buenos Aires, Hyspamérica, 1986.

Carolyn Steedman. "At Every Bloody Level: A Magistrate, a Framework-Knitter, and the Law"; en Law and History Review. The American Society for Legal History, Vol. 30, № 2, May 2012.

Daniel Cabral Marques. "La expansión de los yacimientos estatales en la Patagonia austral y la consolidación de un modelo de regulación sociolaboral bajo la égida de 
YPF: 1930-1946"; en Enrique Mases (comp.). Trabajadores y Trabajadoras en la Argentina. Aportes para una Historia social. Neuquén, Editorial de la Universidad Nacional del Comahue, 2011.

Daniel Cabral Marques. "Mundos del trabajo y formas de organización sindical en la Cuenca del Golfo de San Jorge durante la primera mitad del siglo XX: entre la radicalización obrera, el planteo reivindicativo y la articulación con el Estado"; en Avances del Cesor. Año X, № 10. Rosario, ISHIR-CONICET/UNR, 2013.

Daniel Marquez y Mario Palma Godoy. Comodoro Rivadavia en tiempos de cambio. Una propuesta para la revalorización de nuestras identidades culturales. Comodoro Rivadavia, Ediciones Proyección Patagónica, 1993.

Daniel Marquez. "Conflicto e intervención estatal en los orígenes de la actividad petrolera en Comodoro Rivadavia"; en Daniel Marquez y Mario Palma Godoy. Distinguir y comprender. Aportes para pensar la sociedad y la cultura en Patagonia. Comodoro Rivadavia, Ediciones Proyección Patagónica, 1995.

Débora D’Antonio. "Representaciones de género en la huelga de la construcción. Buenos Aires, 1935-1936"; en Fernanda Gil Lozano, Valeria Silvina Pita y María Gabriela Ini (dirs.). Historia de las mujeres en la Argentina. Siglo XX. Buenos Aires, Taurus, 2000; Tomo II.

Edda Lía Crespo. "De Germinal a Florentino Ameghino. Memoria, política y asociacionismo en Comodoro Rivadavia (1919-1923)"; en Entrepasados, Año X, № 20/21, 2001.

Edward P. Thompson. Miseria de la Teoría. Barcelona, Crítica, 1981.

Edward P. Thompson. Los orígenes de la Ley Negra. Un episodio de la historia criminal inglesa. Buenos Aires, Siglo XXI, 2010.

Florencia D’Uva. "En reclamo de un resarcimiento: trabajadores y accidentes de trabajo en Buenos Aires (1900-1915)"; en este mismo dossier.

Gabriel Carrizo. "Los trabajadores y su tiempo libre. El fútbol en las comunidades obreras de Comodoro Rivadavia durante las primeras décadas del siglo XX"; en Segundas Jornadas de Historia de la Patagonia. Universidad Nacional del Comahue 2, 3 y 4 de noviembre, 2006.

Graciela Ciselli. "Trabajo femenino en la industria petrolera de Chubut (19101962)" en Revista Andes, N 13, 2002.

Graciela Ciselli. "El trabajo femenino en una empresa petrolera privada patagónica. Cambios y continuidades durante el siglo XX" en Revista Avá, № 7, junio de 2003.

Hernán Camarero. A la conquista de la clase obrera. Los comunistas y el mundo del trabajo en la Argentina, 1920-1935. Buenos Aires, Siglo XXI, 2007.

James Scott. Los dominados y el arte de la resistencia. México DF, Era, 2000.

José Sergio Leite López. "Classe, etnicidade e cor na formação do futebol brasileiro"; en Claudio Batalha, Fernando Teixeira da Silva y Aelxandre Fortes (orgs.). Culturas de Clase. Sao Paulo, Unicamp, 2004.

Karina Ramacciotti. "De la culpa al seguro. La Ley de Accidentes de Trabajo, Argentina (1915-1955)”; en Mundos do Trabalho, № 3, 2011.

María Celia Bravo. "Entre la resistencia y el conflicto social. Imágenes de la mujer trabajadora en el área azucarera de Tucumán (1888-1904)”; en María Celia Bravo, Fernanda Gil Lozano y Valeria Silvina Pita (comps.). Historia de luchas, resistencias y representaciones. Mujeres en la Argentina, siglos XIX y XX. Tucumán, EDUNT, 2007. María Teresa Dittler. Pozos. Kilómetro 8. Un pueblo petrolero de la Patagonia. Buenos Aires, Ediciones Vela al Viento/Ediciones Patagónicas, 2011. 


\section{Andrea Andújar}

Mirta Z. Lobato y Silvana Palermo. "Del trabajo a las calles: dignidad, respeto y derechos para las y los trabajadores"; en Mirta Z. Lobato (ed.). Buenos Aires. Manifestaciones, fiestas y rituales en el siglo XX. Buenos Aires, Editorial Biblos, 2011.

Nicolás Gadano. Historia del petróleo en Argentina, 1907-1955: desde los inicios hasta la caída de Perón. Buenos Aires, Edhasa, 2006.

Silvana Palermo. "¿Trabajo Masculino, Protesta Femenina? La participación de la mujer en la gran huelga ferroviaria de 1917"; en María Celia Bravo, Fernanda Gil Lozano y Valeria Silvina Pita (comps.). Historia de luchas, resistencias y representaciones. Mujeres en la Argentina, siglos XIX y XX. Tucumán, EDUNT, 2007.

Susana Torres. "Huelgas petroleras en Patagonia: Inmigrantes europeos, clase y etnicidad (1917-1933)"; en V Jornadas sobre Colectividades. IDES, Buenos Aires, 26 y 27 de octubre de 1995.

Temma Kaplan. "Conciencia femenina y acción colectiva: el caso de Barcelona, 1910-1918"; en J. Amelong y M. Nash (comps.). Historia y género: las mujeres en la Europa moderna y contemporánea. Valencia, Alfonso el Magnánimo, 1990. 